\title{
Performance Evaluation of Ring Cutter in Harvesting Activity
}

\author{
V. Vijaya Lakshmi* and J. Deepika \\ AICRP- Home Science, Professor Jayashankar Telangana State Agricultural University, \\ Rajendranagar mandal, Hyderabad, 500030, Telangana, India \\ *Corresponding author
}

\section{A B S T R A C T}

\section{Keywords \\ Farm women, Ring cutter, Harvesting or Crop cutting \\ Article Info \\ Accepted: \\ 15 March 2019 \\ Available Online: \\ 10 April 2019}

Agriculture is the main source of income in India. Women are actively involved in various agricultural operations wherever the work is monotonous, time taking and recurring like sowing, weeding, harvesting, bundling vegetables etc. Majority of these activities have to be carried out manually either with simple tools or bare hands which leads to injuries, physiological stress, skin allergies and scratches. Hence the present study was taken up to introduce ring cutter in harvesting vegetables and flowers to reduce the stress and improve the work output. Purposive random sampling technique was adopted in selecting 30 farm women in Maheswaram mandal, Rangareddy district of Telangana. Nearly $28 \%$ increase in harvesting activity was found apart from reducing the cuts and scratches on the fingers.

\section{Introduction}

In India the main source of income is from agriculture where mostly rural women workers were involved. Women play a major role in shaping the country's economy through their active participation in agriculture. About 60 per cent of agricultural operations like transplanting, weeding, picking, harvesting, sowing, and bundling are handled exclusively by women while in other jobs they share the work with men. While performing these activities, the women work continuously in awkward and difficult postures. They need to perform the activities in awkward postures and continuously, due to which they are suffering from pain and discomfort in different parts of their body. Due to the shortage of skilled labourers in normal time and also in peak working seasons, agriculture is facing serious challenges. For harvesting, labourers are available by demanding higher cost but they are not affordable to pay.

In India, crop cutting is an important stage in agriculture field operations. Harvesting or cutting of crop can be done in two ways i.e. manually (conventional method) and mechanically (Improved method). Presently Indian farmers are performing crop cutting or harvesting activity by manual method i.e. by 
the use of hands but this method is very lengthy and time consuming. Moreover cutting vegetables or flowers with thorny stems leads to cuts, injuries, rashes and scratches on the fingers of farm women.

So, availability of women friendly tools and equipment is very crucial for women to carry out the farm activities efficiently and without much drudgery for which, the major step in the present time is to modify the design of old technology to reduce their drudgery and increase work efficiency.

The present study introduced a ring cutter to the farmers while harvesting the flowers mainly to increase non-farm working chances to the agricultural labour that is having higher wage, migration of labour force, low income status and to reduce the drudgery of workers.

Singh et al., (2014) conducted a study in Chandangaon village of Chhindwara district of Madhya Pradesh on ergonomic study of farm women during wheat harvesting by improved sickle. A technically prepared serrated sickle was tested on farm women to improve work efficiency and to reduce the drudgery of women. The results revealed that 19.5 per cent of working efficiency was increased by using serrated sickle as an average, one farm woman harvested 50 bundles of wheat by using serrated sickle while only 39 bundles of wheat was harvested through local sickle and using serrated sickle average working heart rate of women was found to be 110 beats/min. Sharma et al., (2015) conducted a study on improving efficiency and reduction in drudgery of farm women in weeding activity by twin wheel hoe. Thirty farm women were selected randomly for the study. The demonstration component included use of improved weeding implement (Twin Wheel Hoe), skill training and exposing advantages. The focus was to change the attitude, skill and knowledge towards recommended practices in the work.
These women traditionally carried out weeding operation by using tools e.g. hand hoes or "khurpi" in squatting and bending position which decreases the work efficiency. In the recommended weeding practices, it was shown that the same amount of work could be done in almost half of the time and work efficiency was increased by 86.3 per cent. Farm women adopted the improved technique as it had increased the efficiency to work, reduced the drudgery and helped in avoiding bending or squatting posture. It lessened the exertion and fatigue to make the farm women comfortable.

\section{Materials and Methods}

The study was carried out on 30 farm women while harvesting flowers and vegetables. After harvesting, women were questioned how they felt while performing activity with ring cutter. Ring cutter is a protective aid made of copper metal. It can be worn to any finger has a ring based on the workers' comfort. It is used in plucking operations while harvesting flowers or vegetables like chilies, brinjal, bhendi etc. Due to Sharpened tapering edges worker could perform the activity for long duration.

Likert scale was prepared which contained totally 21 statements describing the perception level of farm women. Farm woman was asked to respond for each statement and score was assigned as strongly agree (5), agree (4), not sure (3), disagree (2) and strongly disagree (1). Frequency and percentages were used for statistical analysis.

\section{Results and Discussion}

Results of the present study were presented below with the following discussion in detail. The results revealed that majority of the women $(43.33 \%)$ harvesting flowers in the farm were in between 31-40 years followed by below 30 years $(23.33 \%)$, above 51 years 
(20.00\%) and between 41-50 years (13.33\%). Nearly forty three per cent of the farm women had below 10 years of work experience whereas only 6.67 per cent of farm women had between 31- 40 years work experience which implies that since the sample comprised of only 20 per cent of women aged above 51 years, they had long years of work experience.

Ring cutter was given as an intervention to the sample in plucking flowers and vegetables. In conventional method, they pluck flowers and vegetables with bare hands which inflict pain on the fingers, especially with okra chillies and chrysanthemum, they have cuts scratches and itching on the fingers. All the sample were given ring cutter to use it for one day completely after practicing it. A 5 point likert scale was used to find out the performance evaluation of a ring cutter. Five score was given if sample had strongly agreed with the statement while one score was given when they had strongly disagreed with in between 4 for agree, 3 for not sure and 2 for disagree. Responses on each statement were scored and total score was obtained. Based on the total score, ranking was given.

From table 3, findings of the study revealed that based on ranking order, highest number of farm women said that the ring cutter can be used for plucking more than one crop and while using ring cutter they felt uncomfortable to twist hand.

Majority of them disagreed that ring cutter was uncomfortable to twist hand, hands were painful while using, increased heartbeat, surface touches hard to skin (60\%), pain was felt in forearms, fingers and shoulders, occurrence of hand injuries etc. which implies that women were comfortable with the use of ring cutter. Fifty per cent agreed that pressure is reduced on wrist, movement of hand fingers was according to the movement of cutter $(40 \%)$, comfortable to hold it, light in weight and comfortable to use, easy to store etc. (Table 1-3; Fig. 1-4).

Table.1 Distribution of sample by age

\begin{tabular}{|l|c|c|r|}
\hline Age in years & Frequency & Percentages $(\%)$ & Mean \pm S.D \\
\hline Below 30 years & 7 & 23.33 & \\
\cline { 1 - 3 } Between 31-40 years & 13 & 43.33 & \multirow{2}{*}{$39.17 \pm 12.2$} \\
\cline { 1 - 3 } Between 41-50 years & 4 & 13.33 & \\
\hline Above 51 years & 6 & 20.00 & \\
\hline
\end{tabular}

Table.2 Distribution of sample by work experience

$(\mathbf{N}=30)$

\begin{tabular}{|l|c|c|c|}
\hline Work experience in years & Frequency & Percentages $(\%)$ & Mean \pm S.D \\
\hline Below 10 years & 13 & 43.33 & \\
\cline { 1 - 3 } Between 11-20 years & 8 & 26.67 & \multirow{2}{*}{$20.50 \pm 13.8$} \\
Between 21-30 years & 4 & 13.33 & \\
\cline { 1 - 3 } Between 31-40 years & 2 & 6.67 & \\
\hline Above 41 years & 3 & 10.00 & \\
\cline { 1 - 3 } & & &
\end{tabular}


Table.3 Distribution of respondents by ranking the ring cutter based on perception level of farm women

\begin{tabular}{|c|c|c|c|c|c|c|c|c|}
\hline & & & & & & \multicolumn{3}{|c|}{$(\mathrm{N}=30)$} \\
\hline S.No & Statements & $\begin{array}{l}\text { Strongly } \\
\text { Agree (5) }\end{array}$ & $\begin{array}{l}\text { Agree } \\
\text { (4) }\end{array}$ & $\begin{array}{l}\text { Not sure } \\
\text { (3) }\end{array}$ & $\begin{array}{c}\text { Disagree } \\
\text { (2) }\end{array}$ & $\begin{array}{l}\text { Strongly } \\
\text { Disagree } \\
\text { (1) }\end{array}$ & $\begin{array}{l}\text { Total } \\
\text { Score }\end{array}$ & $\begin{array}{c}\text { Ranking } \\
\text { order }\end{array}$ \\
\hline 1. & $\begin{array}{l}\text { Uncomfortable to twist hand while } \\
\text { using ring cutter }\end{array}$ & $\begin{array}{c}3 \\
(10.00 \%)\end{array}$ & $\begin{array}{c}7 \\
(23.33 \%)\end{array}$ & $\begin{array}{c}4 \\
(13.33 \%)\end{array}$ & $\begin{array}{c}15 \\
(50.00 \%)\end{array}$ & $\begin{array}{c}1 \\
(3.33 \%)\end{array}$ & 86 & 15 \\
\hline 2. & $\begin{array}{l}\text { Pressure is reduced on wrist due to } \\
\text { the usage of ring cutter }\end{array}$ & $\begin{array}{c}2 \\
(6.67 \%)\end{array}$ & $\begin{array}{c}15 \\
(50.00 \%)\end{array}$ & $\begin{array}{c}3 \\
(10.00 \%)\end{array}$ & $\begin{array}{c}9 \\
(30.00 \%)\end{array}$ & $\begin{array}{c}1 \\
(3.33 \%)\end{array}$ & 98 & 11 \\
\hline 3. & $\begin{array}{l}\text { Hand fingers can be moved as per the } \\
\text { movement of cutter }\end{array}$ & $\begin{array}{c}8 \\
(26.67 \%)\end{array}$ & $\begin{array}{c}12 \\
(40.00 \%)\end{array}$ & $\begin{array}{c}4 \\
(13.33 \%)\end{array}$ & $\begin{array}{c}6 \\
(20.00 \%)\end{array}$ & - & 112 & 7 \\
\hline 4. & $\begin{array}{l}\text { Get perspired and hands are painful } \\
\text { due to the use of ring cutter }\end{array}$ & - & $\frac{2}{(6.67 \%)}$ & $\frac{3}{(10.00 \%)}$ & $\frac{19}{(63.33 \%)}$ & $\frac{6}{(20.00 \%)}$ & 61 & 19 \\
\hline 5. & $\begin{array}{l}\text { Increase in heartbeat, vibration in } \\
\text { shoulders occur }\end{array}$ & - & - & $\begin{array}{c}3 \\
(10.00 \%)\end{array}$ & $\begin{array}{c}17 \\
(56.67 \%)\end{array}$ & $\begin{array}{c}10 \\
(33.33 \%)\end{array}$ & 53 & 21 \\
\hline 6. & Comfortable to hold ring cutter & $\begin{array}{c}6 \\
(20.00 \%)\end{array}$ & $\begin{array}{c}19 \\
(63.33 \%)\end{array}$ & $\begin{array}{c}4 \\
(13.33 \%)\end{array}$ & $\begin{array}{c}1 \\
(3.33 \%)\end{array}$ & - & 120 & 4 \\
\hline 7. & $\begin{array}{l}\text { Surface of ring cutter touches hard } \\
\text { and coarse to the skin/hand }\end{array}$ & - & $\begin{array}{c}4 \\
(13.33 \%) \\
\end{array}$ & $\begin{array}{c}4 \\
(13.33 \%) \\
\end{array}$ & $\begin{array}{c}18 \\
(60.00 \%)\end{array}$ & $\begin{array}{c}4 \\
(13.33 \%) \\
\end{array}$ & 68 & 18 \\
\hline 8. & $\begin{array}{l}\text { Pain is felt in forearms, fingers and } \\
\text { shoulders due to the use of ring cutter }\end{array}$ & $\begin{array}{c}4 \\
(13.33 \%)\end{array}$ & $\begin{array}{c}7 \\
(23.33 \%) \\
\end{array}$ & $\begin{array}{c}1 \\
(3.33 \%)\end{array}$ & $\begin{array}{c}18 \\
(60.00 \%)\end{array}$ & - & 87 & 14 \\
\hline 9. & $\begin{array}{l}\text { No sprains/pain in nerves and hand } \\
\text { while using cutter }\end{array}$ & - & $\begin{array}{c}10 \\
(33.33 \%) \\
\end{array}$ & $\begin{array}{c}1 \\
(3.33 \%)\end{array}$ & $\begin{array}{c}15 \\
(50.00 \%) \\
\end{array}$ & $\begin{array}{c}4 \\
(13.33 \%) \\
\end{array}$ & 77 & 16 \\
\hline 10. & $\begin{array}{l}\text { Hand injury occurs due to the use of } \\
\text { ring cutter }\end{array}$ & - & - & $\begin{array}{c}2 \\
(6.67 \%)\end{array}$ & $\begin{array}{c}21 \\
(70 \%)\end{array}$ & $\begin{array}{c}7 \\
(23.33 \%) \\
\end{array}$ & 55 & 20 \\
\hline 11. & $\begin{array}{l}\text { Flowers/Vegetables could be } \\
\text { plucked easily due to the use of ring } \\
\text { cutter }\end{array}$ & $\begin{array}{c}4 \\
(13.33 \%)\end{array}$ & $\begin{array}{c}14 \\
(46.67 \%)\end{array}$ & $\begin{array}{c}11 \\
(36.67 \%)\end{array}$ & $\begin{array}{c}1 \\
(3.33 \%)\end{array}$ & - & 111 & 8 \\
\hline 12. & $\begin{array}{l}\text { Work is completed fast due to ring } \\
\text { cutter }\end{array}$ & $\begin{array}{c}5 \\
(16.67 \%)\end{array}$ & $\begin{array}{c}12 \\
(40.00 \%)\end{array}$ & $\begin{array}{c}10 \\
(33.33 \%)\end{array}$ & $\begin{array}{c}3 \\
(10.00 \%)\end{array}$ & - & 109 & 9 \\
\hline 13. & $\begin{array}{l}\text { It is light in weight and comfortable } \\
\text { to use }\end{array}$ & $\begin{array}{c}7 \\
(23.33 \%)\end{array}$ & $\begin{array}{c}19 \\
(63.33 \%)\end{array}$ & $\begin{array}{c}2 \\
(6.67 \%)\end{array}$ & $\begin{array}{c}2 \\
(6.67 \%)\end{array}$ & - & 121 & 3 \\
\hline 14. & $\begin{array}{l}\text { Shape and size of cutter is } \\
\text { comfortable to be used for hand } \\
\text { plucking of flowers and vegetables }\end{array}$ & $\begin{array}{c}10 \\
(33.33 \%)\end{array}$ & $\begin{array}{c}14 \\
(46.67 \%)\end{array}$ & $\begin{array}{c}4 \\
(13.33 \%)\end{array}$ & $\begin{array}{c}2 \\
(6.67 \%)\end{array}$ & - & 122 & 2 \\
\hline 15. & It is easy to store ring cutter & $\begin{array}{c}4 \\
(13.33 \%)\end{array}$ & $\begin{array}{c}18 \\
(60.00 \%)\end{array}$ & $\begin{array}{c}7 \\
(23.33 \%)\end{array}$ & $\begin{array}{c}1 \\
(3.33 \%)\end{array}$ & - & 115 & 6 \\
\hline 16. & $\begin{array}{l}\text { It is not difficult to maintain and } \\
\text { repair ring cutter }\end{array}$ & $\begin{array}{c}2 \\
(6.67 \%)\end{array}$ & $\begin{array}{c}10 \\
(33.33 \%)\end{array}$ & $\begin{array}{c}9 \\
(30.00 \%)\end{array}$ & $\begin{array}{c}8 \\
(26.67 \%)\end{array}$ & $\begin{array}{c}1 \\
(3.33 \%)\end{array}$ & 94 & 13 \\
\hline 17. & $\begin{array}{l}\text { Ring cutter parts are quite intact and } \\
\text { stable }\end{array}$ & $\begin{array}{c}5 \\
(16.67 \%)\end{array}$ & $\begin{array}{c}5 \\
(16.67 \%)\end{array}$ & $\begin{array}{c}11 \\
(36.67 \%)\end{array}$ & $\begin{array}{c}9 \\
(30.00 \%)\end{array}$ & - & 96 & 12 \\
\hline 18. & $\begin{array}{l}\text { Ring cutter is better option for } \\
\text { plucking vegetables as compared to } \\
\text { conventional method }\end{array}$ & $\begin{array}{c}9 \\
(30.00 \%)\end{array}$ & $\begin{array}{c}11 \\
(36.67 \%)\end{array}$ & $\begin{array}{c}8 \\
26.67 \%)\end{array}$ & $\begin{array}{c}2 \\
(6.67 \%)\end{array}$ & - & 117 & 5 \\
\hline 19. & $\begin{array}{l}\text { Ring cutter can be used for plucking } \\
\text { more than one crop }\end{array}$ & $\begin{array}{c}15 \\
(50.00 \%)\end{array}$ & $\begin{array}{c}6 \\
(20.00 \%)\end{array}$ & $\begin{array}{c}9 \\
(30.00 \%)\end{array}$ & - & - & 126 & 1 \\
\hline 20. & Cost of tool is within my budget & $\begin{array}{c}4 \\
(13.33 \%)\end{array}$ & $\begin{array}{c}10 \\
(33.33 \%)\end{array}$ & $\begin{array}{c}11 \\
(36.67 \%)\end{array}$ & $\begin{array}{c}4 \\
(13.33 \%)\end{array}$ & $\begin{array}{c}1 \\
(3.33 \%)\end{array}$ & 102 & 10 \\
\hline 21. & $\begin{array}{l}\text { Doubtful about procuring ring cutter } \\
\text { due to the non-cooperation of family } \\
\text { members }\end{array}$ & $\begin{array}{c}1 \\
(3.33 \%)\end{array}$ & $\begin{array}{c}1 \\
(3.33 \%)\end{array}$ & $\begin{array}{c}16 \\
(53.33 \%)\end{array}$ & $\begin{array}{c}7 \\
(23.33 \%)\end{array}$ & $\begin{array}{c}5 \\
(16.67 \%)\end{array}$ & 76 & 17 \\
\hline
\end{tabular}


Fig.1\&2 Scratches on fingers due to manual harvesting \& Ring cutter
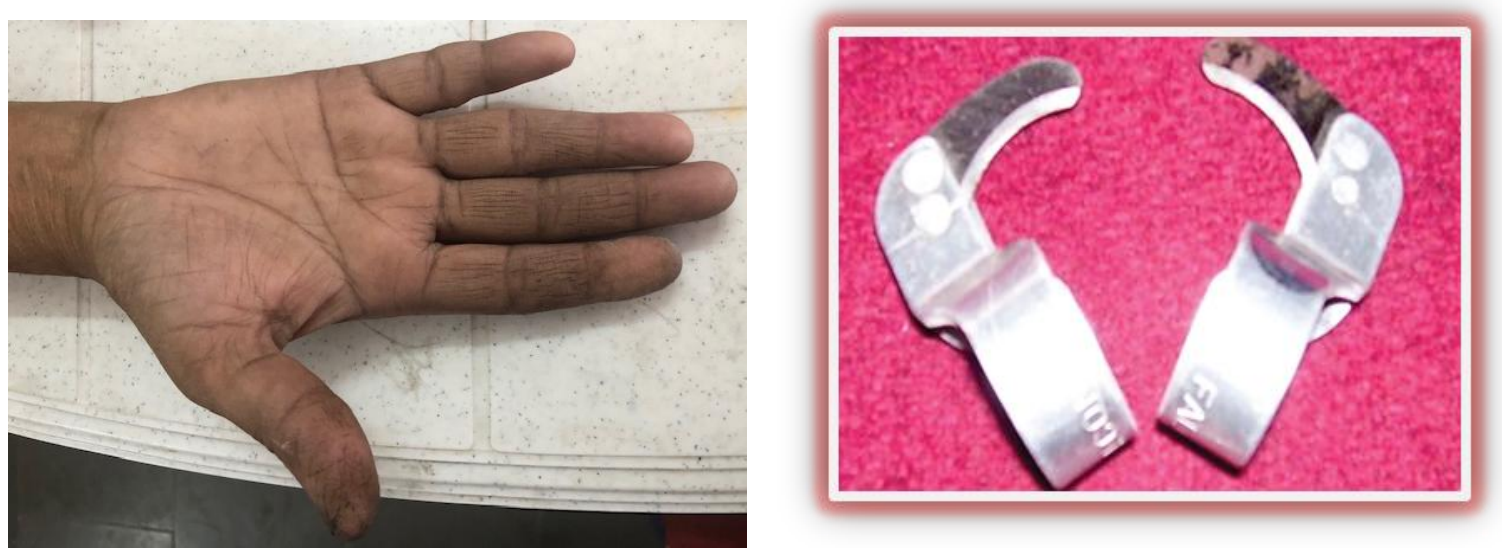

Fig.3\&4 Use of ring cutter in Okra field \& Use of ring cutter in Chrysanthemum field

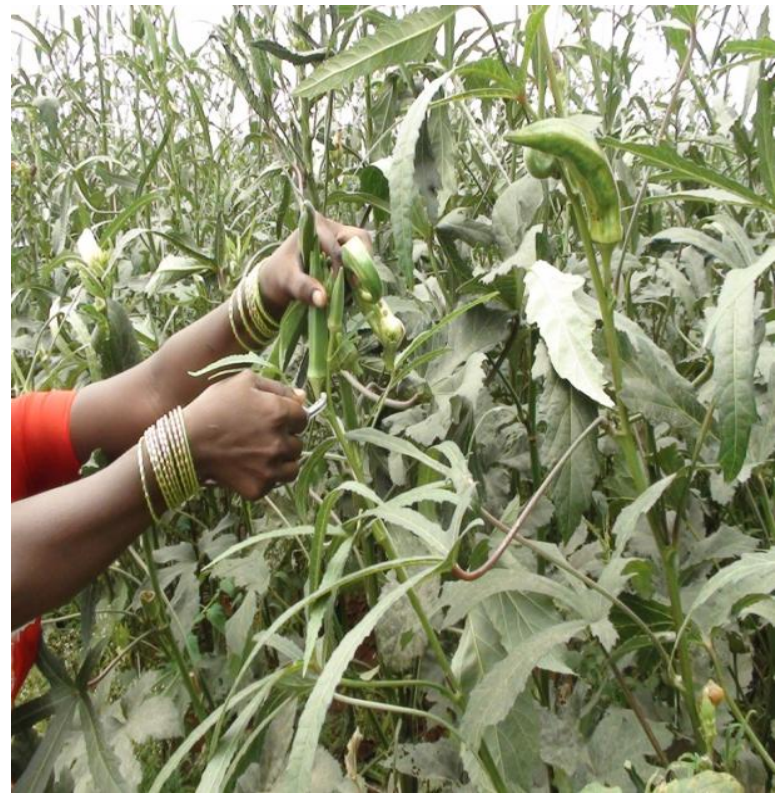

In conclusion, majority of the respondents strongly agreed that ring cutter can be used for plucking more than one crop as they tried in okra field too other than flowers. Some of them opined that it can be used for harvesting brinjal, bottle gourd, rose etc. It was also found that farmers can harvest up to 20-22 kgs in traditional method where as by using ring cutter one can harvest up to $35 \mathrm{kgs}$ in a day which implies that ring cutter can be given in okra, chillies, brinjal and flower crops like roses, chrysanthemum etc. Ring

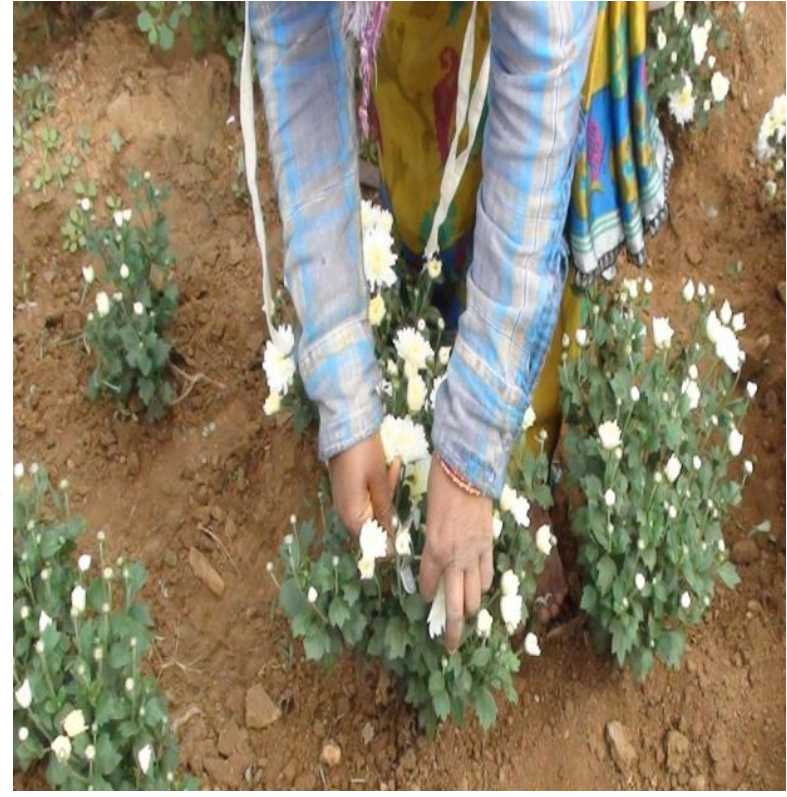

cutter not only improves the work performance of the farmers so that labour cost can be reduced in harvesting, but also improves the health conditions of fingers from scratches, injuries and cuts.

\section{Acknowledgement}

The authors sincerely thank the participants of the study, without which this report wouldn't have been possible. 


\section{References}

Singh, A., Gautam, U.S., Singh, $\mathrm{R}$ and Paliwal, D. 2014. Ergonomic study of farm women during wheat harvesting by improved sickle. African journal of agricultural research. 9(18): 13861390.
Sharma, B., Singh, S.R.K., Gupta, S., Shrivastava, M.K and Verma, S. 2015. Improving efficiency and reduction in drudgery of farm women in weeding activity by twin wheel hoe. Indian Research journal of extension education. 15(1): 76-80.

\section{How to cite this article:}

Vijaya Lakshmi, V. and Deepika, J. 2019. Performance Evaluation of Ring Cutter in Harvesting Activity. Int.J.Curr.Microbiol.App.Sci. 8(04): 1838-1843.

doi: https://doi.org/10.20546/ijcmas.2019.804.214 